\title{
UPAYA PENINGKATAN SUPERVISI DAN KOMPETENSI GURU DALAM PENYUSUNAN RENCANA PELAKSANAAN PEMBELAJARAN HARIAN (RPPH) DI TAMAN KANAK-KANAK ASYIYAH BUSTANUL ATFAL IVKECAMATAN JELUTUNG KOTA JAMBI TAHUN 2017
}

\author{
Zulekha \\ TK Islam Al-Kautsar Kota Jambi \\ Email: zylekhasuar26@gmail.com
}

\begin{abstract}
ABSTRAK
Setiap proses pasti selalu meliputi tiga kegaiatan utama yakni perencanaan, pelaksanaan dan evaluasi. Demikian pula yang terjadi dengan proses belajar mengajar di sekolah. Seorang guru diharuskan melakukan perencanaan, pelaksanaan dan evaluasi pembelajaran.

Proses perencanaan pembelajaran yang harus dilakukan oleh seorang guru meliputi kegiatan utama membuat program tahunan. membuat program semester. membuat rencana pelaksanaan pembelajaran. Berdasarkan kepada hasil analisa pada tahun pelajaran 2016/2017, muncul permasalahan rendahnya guru yang membuat perencanaan pembelajaran khususnya penyusunan RPPH. Untuk meneliti lemahnya kinerja guru dalam hal tersebut, dilakukanlah penelitian untuk melihat sejauhmana langkah supervisi akademik kepala sekolah dapat meningkatkan kompetensi guru dalam penyusunan Rencana Pelaksanaan Pembelajaran.

Adapun kegiatan penelitian tindakan sekolah ini adalah untuk mengetahui efektivitas upaya peningkatan keterampilan guru dalam penerapan Supervisi dan Kompetensi Guru dalam Penyusunan RPPH di Taman Kanak-Kanak Asyiyyah IV. Sedangkan secara umum, tujuan kegiatan penelitian tindakan sekolah ini adalah untuk peningkatan kualitas proses dan hasil belajar di Taman KanakKanak Asyiyyah IV.
\end{abstract}

\section{Kata Kunci: Supervisi, Kompetensi Guru, RPPH}

\section{A. PENDAHULUAN}

\section{Latar Belakang}

Pendidikan selalu berorientasi pada perubahan, karena setiap perubahan adalah proses yang harus dilalui peserta didik dan pendidik dengan selalau memperhatikan mutu dan tujuan.(Pohan, 2018) Pendidikan merupakan investasi dalam pengembangan sumber daya manusia dan dipandang sebagai kebutuhan dasar bagi masyarakat yang ingin maju. Komponen-komponen sistem pendidikan yang mencakup sumber daya manusia dapat digolongkan menjadi dua yaitu: 
tenaga kependidikan guru dan nonguru. Menurut Undang-Undang Nomor 2 tahun 1989 tentang Sistem Pendidikan Nasional menyatakan, "komponen-komponen sistem pendidikan yang bersifat sumber daya manusia dapat digolongkan menjadi tenaga pendidik dan pengelola satuan pendidikan (penilik, pengawas, peneliti dan pengembang pendidikan)." Tenaga gurulah yang mendapatkan perhatian lebih banyak di antara komponen-komponen sistem pendidikan. Besarnya perhatian terhadap guru antara lain dapat dilihat dari banyaknya kebijakan khusus seperti kenaikan tunjangan fungsional guru dan sertifikasi guru.

Usaha-usaha untuk mempersiapkan guru menjadi profesional telah banyak dilakukan. Kenyataan menunjukkan bahwa tidak semua guru memiliki kinerja yang baik dalam melaksanakan tugasnya. "Hal itu ditunjukkan dengan kenyataan (1) guru sering mengeluh kurikulum yang berubah-ubah, (2) guru sering mengeluhkan kurikulum yang syarat dengan beban, (3) seringnya siswa mengeluh dengan cara mengajar guru yang kurang menarik, (4) masih belum dapat dijaminnya kualitas pendidikan sebagai mana mestinya" (Imron, 2000:5).

Berdasarkan kenyataan begitu berat dan kompleksnya tugas serta peran guru tersebut, perlu diadakan supervisi atau pembinaan terhadap guru secara terus menerus untuk meningkatkan kinerjanya. Kinerja guru perlu ditingkatkan agar usaha membimbing siswa untuk belajar dapat berkembang. Proses kinerja guru harus di dukung dengan peran seorang pemimpin sekolah(Sumarto, 2016) yang mampu memberikan perubahan.

"Proses pengembangan kinerja guru terbentuk dan terjadi dalam kegiatan belajar mengajar di tempat mereka bekerja. Selain itu kinerja guru dipengaruhi oleh hasil pembinaan dan supervisi kepala sekolah" (Pidarta, 1992:3). Pada pelaksanaan KTSP menuntut kemampuan baru pada guru untuk dapat mengelola proses pembelajaran secara efektif dan efisien. Tingkat produktivitas sekolah dalam memberikan pelayanan-pelayanan secara efisien kepada pengguna (peserta didik, masyarakat) akan sangat tergantung pada kualitas gurunya yang terlibat langsung dalam proses pembelajaran dan keefektifan mereka dalam melaksanakan tanggung jawab individual dan kelompok. 
Direktorat Pembinaan SMA (2008:3) menyatakan "kualitas pendidikan sangat ditentukan oleh kemampuan sekolah dalam mengelola proses pembelajaran, dan lebih khusus lagi adalah proses pembelajaran yang terjadi di kelas, mempunyai andil dalam menentukan kualitas pendidikan konsekuensinya, adalah guru harus mempersiapkan (merencanakan) segala sesuatu agar proses pembelajaran di kelas berjalan dengan efektif".

Hal ini berarti bahwa guru sebagai fasilitator yang mengelola proses pembelajaran di kelas mempunyai andil dalam menentukan kualitas pendidikan. Konsekuensinya adalah guru harus mempersiapkan (merencanakan) segala sesuatu agar proses pembelajaran di kelas berjalan dengan efektif.

Perencanaan pembelajaran merupakan langkah yang sangat penting sebelum pelaksanaan pembelajaran. Perencanaan yang matang diperlukan supaya pelaksanaan pembelajaran berjalan secara efektif. Perencanaan pembelajaran dituangkan ke dalam Rencana Pelaksanaan Pembelajaran Harian (RPPH) atau beberapa istilah lain seperti desain pembelajaran, skenario pembelajaran. RPPH memuat KD, indikator yang akan dicapai, materi yang akan dipelajari, metode pembelajaran, langkah pembelajaran, media pembelajaran, dan sumber belajar serta penilaian.

Peraturan Pemerintah Nomor 19 Tahun 2005 tentang 8 Standar Nasional Pendidikan menyatakan standar proses merupakan salah satu SNP untuk satuan pendidikan dasar dan menengah yang mencakup: 1) Perencanaan proses pembelajaran, 2) Pelaksanaan proses pembelajaran, 3) Penilaian hasil pembelajaran, 4) dan pengawasan proses pembelajaran. Perencanaan pembelajaran meliputi Silabus dan Rencana Pelaksanaan Pembelajaran Harian (RPPH).

Silabus dan RPPH dikembangkan oleh guru pada satuan pendidikan . Guru pada satuan pendidikan berkewajiban menyusun Silabus dan RPPH secara lengkap dan sistematis agar pembelajaran berlangsung secara interaktif, inspiratif, menyenangkan, menantang, memotivasi peserta didik untuk berpartisipasi aktif, serta memberikan ruang yang cukup bagi prakarsa, kreativitas, dan kemandirian sesuai dengan bakat, minat dan perkembangan fisik serta psikologis peserta didik. 
Masalah yang terjadi di lapangan masih ditemukan adanya guru (baik di sekolah negeri maupun swasta) yang tidak bisa memperlihatkan RPPH yang dibuat dengan alasan ketinggalan di rumah dan bagi guru yang sudah membuat RPPH masih ditemukan adanya guru yang belum melengkapi komponen tujuan pembelajaran dan penilaian peserta didik, serta langkah-langkah kegiatan pembelajarannya masih dangkal. Sebagian besar guru khususnya di sekolah swasta belum mendapatkan pelatihan pengembangan RPPH. Selama ini guru-guru yang mengajar di sekolah swasta sedikit/jarang mendapatkan kesempatan untuk mengikuti berbagai Diklat Peningkatan Profesionalisme Guru dibandingkan sekolah negeri. Hal ini menyebabkan banyak guru yang belum tahu dan memahami penyusunan/pembuatan RPPH secara baik/lengkap. Beberapa guru mengadopsi RPPH orang lain. Hal ini peneliti ketahui pada saat mengadakan supervisi akademik (supervisi kunjungan kelas) ke sekolah binaan. Permasalahan tersebut berpengaruh besar terhadap pelaksanaan proses pembelajaran.

Dengan keadaan demikian, peneliti sebagai pembina sekolah berusaha untuk memberi bimbingan berkelanjutan pada guru dalam menyusun RPPH secara lengkap sesuai dengan tuntutan pada standar proses dan standar penilaian yang merupakan bagian dari standar nasional pendidikan. Hal itu juga sesuai dengan Tupoksi peneliti sebagai kepala sekolah berdasarkan Permendiknas No.16 Tahun 2007 tentang standar kompetensi guru yaitu pedagogik, kepribadian, sosial dan profesional.

Rencana Pelaksanaan Pembelajaran Harian harus dibuat agar kegiatan pembelajaran berjalan sistematis dan mencapai tujuan pembelajaran. Tanpa Rencana Pelaksanaan Pembelajaran Harian, biasanya pembelajaran menjadi tidak terarah. Oleh karena itu, guru harus mampu menyusun RPPH dengan lengkap berdasarkan silabus yang disusunnya. Rencana Pelaksanaan Pembelajaran Harian sangat penting bagi seorang guru karena merupakan acuan dalam melaksanakan proses pembelajaran. 


\section{Perumusan Masalah}

Berdasarkan latar belakang di atas diajukan rumusan masalah sebagai berikut "Apakah dengan bimbingan berkelanjutan akan dapat meningkatkan kompetensi guru dalam menyusun RPPH?"

\section{Tujuan Penelitian}

Penelitian Tindakan Sekolah (PTS) ini bertujuan untuk meningkatkan kompetensi guru dalam menyusun Rencana Pelaksanaan Pembelajaran Harian melalui bimbingan berkelanjutan di TK Aisyiyah Bustanul Athfal IV, J1. Nias Kel. Handil Jaya Kec.Jelutung.

\section{Manfaat Penelitian}

1) Manfaat bagi peneliti

a. Meningkatkan kemampuan profesionalisme peneliti untuk melakukan penelitian tindakan sekolah sesuai dengan permasalahan yang dihadapi di sekolah binaan peneliti.

b. Meningkatkan kemampuan peneliti dalam menyusun serta menulis laporan dan artikel ilmiah.

c. Sebagai motivasi bagi peneliti dalam membuat karya tulis ilmiah.

d. Hasil penelitian ini dapat digunakan oleh peneliti sebagai syarat untuk kenaikan golongan ke- IV b.

e. Dengan adanya pengalaman menulis, dapat memberikan bimbingan kepada teman-teman pengawas dan guru yang akan menulis.

f. Hasil penelitian ini digunakan peneliti sebagai evaluasi terhadap guru dalam menyusun RPPH yang selanjutnya akan digunakan sebagai bahan pembinaan kepada guru di sekolah.

2) Manfaat bagi sekolah

a. Akan berdampak adanya peningkatan administrasi guru pada KBM yang lebih lengkap.

b. Dapat meningkatkan kualitas pendidikan karena Standar Kompetensi dan Kompetensi Dasar sudah tersampaikan. 
3) Manfaat bagi guru

a. Dapat meningkatkan kompetensi dalam membuat RPPH dengan lengkap serta menciptakan kesadaran guru tentang tanggung jawabnya terhadap pelaksanaan tugasnya.

b. Sebagai panduan dan arahan dalam mengajar sehingga apa yang diinginkan dalam standar isi dapat tersampaikan.

\section{B. KAJIAN PUSTAKA}

\section{Pengertian Guru}

Secara etimologi (asal usul kata), istilah "Guru" berasal dari bahasa India yang artinya "orang yang mengajarkan tentang kelepasan dari sengsara" Shambuan, Republika, (dalam Suparlan 2005:11).

Poerwadarminta (dalam Suparlan 2005:13) menyatakan, "guru adalah orang yang kerjanya mengajar." Dengan definisi ini, guru disamakan dengan pengajar. Pengertian guru ini hanya menyebutkan satu sisi yaitu sebagai pengajar, tidak termasuk pengertian guru sebagai pendidik dan pelatih. Selanjutnya Zakiyah Daradjat (dalam Suparlan 2005:13) menyatakan," guru adalah pendidik profesional karena guru telah menerima dan memikul beban dari orang tua untuk ikut mendidik anak-anak."

UU Guru dan Dosen Republik Indonesia No.14 Tahun 2005 "Guru adalah pendidik profesional dengan tugas utama mendidik, mengajar, membimbing, mengarahkan, melatih, menilai, dan mengevaluasi peserta didik pada pendidikan anak usia dini jalur pendidikan formal, pendidikan dasar, dan pendidikan menengah".

Selanjutnya UU No.20 Tahun 2003 pasal 39 ayat 2 tentang sistem pendidikan nasional menyatakan, "pendidik merupakan tenaga profesional yang bertugas merencanakan dan melaksanakan proses pembelajaran, menilai hasil pembelajaran, melakukan pembimbingan dan pelatihan, serta melakukan penelitian dan pengabdian kepada masyarakat, terutama bagi pendidik pada perguruan tinggi." 
PP No.19 Tahun 2005 tentang Standar Nasional Pendidikan menyatakan, “pendidik (guru) harus memiliki kualifikasi akademik dan kompetensi sebagai agen pembelajaran, sehat jasmani dan rohani, serta memiliki kemampuan untuk mewujudkan tujuan pendidikan nasional."

Berdasarkan definisi di atas, dapat disimpulkan bahwa guru adalah tenaga pendidik yang profesional dengan tugas utama mendidik, mengajar, membimbing, mengarahkan, melatih, menilai dan mengevaluasi peserta didik, dan bertugas merencanakan dan melaksanakan proses pembelajaran.

\section{Standar Kompetensi Guru}

Kompetensi diartikan sebagai pengetahuan, keterampilan, dan nilai-nilai dasar yang direfleksikan dalam kebiasaan berfikir dan bertindak (Dalam Suparlan). Arti lain dari kompetensi adalah spesifikasi dari pengetahuan, keterampilan, dan sikap yang dimiliki seseorang serta penerapannya di dalam pekerjaan, sesuai dengan standar kinerja yang dibutuhkan oleh lapangan.

Undang-Undang Guru dan Dosan No.14 Tahun 2005 Pasal 8 menyatakan, "guru wajib memiliki kualifikasi akademik, kompetensi, sertifikat pendidik, sehat jasmani dan rohani, serta memiliki kemampuan untuk mewujudkan tujuan pendidikan nasional." Dari rumusan di atas jelas disebutkan pemilikan kompetensi oleh setiap guru merupakan syarat yang mutlak harus dipenuhi oleh guru. Dengan demikian, kompetensi yang dimiliki oleh setiap guru akan menunjukkan kualitas guru yang sebenarnya.

Selanjutnya Pasal 10 menyebutkan empat kompetensi yang harus dimiliki oleh guru yakni (1) kompetensi pedagogik, (2) kompetensi kepribadian, (3) kompetensi sosial, dan (4) kompetensi profesional. Kompetensi tersebut akan terwujud dalam bentuk penguasaan pengetahuan, keterampilan, maupun sikap profesional dalam menjalankan fungsi sebagai guru.

\section{Tujuan dan Manfaat Standar Kompetensi Guru}

Depdiknas (2004: 4) tujuan adanya Standar Kompetensi Guru adalah sebagai jaminan dikuasainya tingkat kompetensi minimal oleh guru sehingga yang

VOLUME 2, NO. 1 Januari - Juni 2019 
bersangkutan dapat melakukan tugasnya secara profesional, dapat dibina secara efektif dan efisien serta dapat melayani pihak yang berkepentingan terhadap proses pembelajaran, dengan sebaik-baiknya sesuai bidang tugasnya. Adapun manfaat disusunnya standar kompetensi guru adalah sebagai acuan pelaksanaan uji kompetensi, penyelenggaraan diklat, dan pembinaan, maupun acuan bagi pihak yang berkepentingan terhadap kompetensi guru untuk melakukan evaluasi, pengembangan bahan ajar dan sebagainya bagi tenaga kependidikan.

\section{Rencana Pelaksanaan Pembelajaran Harian}

Perencanaan proses pembelajaran meliputi silabus dan RPPH. Silabus merupakan sebagian sub-sistem pembelajaran yang terdiri dari atau yang satu sama yang lain saling berhubungan dalam rangka mencapai tujuan. Hal penting yang berkaitan dengan pembelajaran adalah penjabaran tujuan yang disusun berdasarkan indikator yang ditetapkan.

Philip Combs (dalam Kurniawati, 2009:66) menyatakan bahwa perencanaan program pembelajaran merupakan suatu penetapan yang memuat komponen-komponen pembelajaran secara sistematis. Analisis sistematis merupakan proses perkembangan pendidikan yang akan mencapai tujuan pendidikan agar lebih efektif dan efisien disusun secara logis, rasional, sesuai dengan kebutuhan siswa, sekolah, dan daerah (masyarakat). Perencanaan program pembelajaran adalah hasil pemikiran, berupa keputusan yang akan dilaksanakan.

Selanjutnya Oemar Hakim (dalam Kurniawati 2009:74) menyatakan, "bahwa perencanaan program pembelajaran pada hakekatnya merupakan perencanaan program jangka pendek untuk memperkirakan suatu proyeksi tentang sesuatu yang akan dilakukan dalam kegiatan pembelajaran”.

Permendiknas No. 41 Tahun 2007 menyatakan, "Rencana Pelaksanaan Pembelajaran (RPPH) adalah rencana yang menggambarkan prosedur dan pengorganisasian pembelajaran untuk mencapai satu kompetensi dasar yang ditetapkan dalam standar isi dan telah dijabarkan dalam silabus.”

Dalam KTSP, guru bersama warga sekolah berupaya menyusun kurikulum dan perencanaan program pembelajaran, meliputi: program tahunan, program VOLUME 2, NO. 1 Januari - Juni 2019 
semester, silabus, dan rencana peleksanaan pembelajaran. Rencana Pelaksanaan Pembelajaran dijabarkan dari silabus untuk mengarahkan kegiatan belajar peserta didik dalam upaya mencapai Kompetensi Dasar. RPPH merupakan acuan guru dalam melaksanakan pembelajaran untuk setiap KD. Oleh karena itu, apa yang tertuang di dalam RPPH memuat hal-hal yang langsung berkaitan dengan aktivitas pembelajaran dalam upaya pencapaian penguasaan suatu KD.

\section{Komponen Rencana Pelaksanaan Pembelajaran}

Sesuai Kurikulum 2013, Komponen RPPH terdiri dari : (1) Identitas Program, (2) Materi (3) Alat dan Bahan (4) Kegiatan Pembukaan (5) Kegiatan inti (6) Kegiatan Pentup (7) Rencana Penilaian.

Peraturan Pemerintah Republik Indonesia No. 19 (2005 pasal 20) menyatakan bahwa, "RPPH minimal memuat sekurang-kurangnya lima komponen yang meliputi: (1) tujuan pembelajaran, (2) materi ajar, (3) metode pengajaran, (4) sumber belajar, dan (5) penilaian hasil belajar."

\section{METODE PENELITIAN}

\section{- Setting Penelitian}

Penelitian Tindakan Sekolah dilaksanakan di salah satu Taman Kanak-Kanak berstatus Swasta yaitu TK Aisyiyah Bustanul Atfal IV Kec. Jelutung. PTS ini dilaksanakan pada semester satu tahun 2016 selama kurang lebih satu setengah bulan mulai Agustus sampai dengan Oktober 2016.

\section{- Subjek Penelitian}

Yang menjadi subyek dalam PTS ini adalah guru TK Aisyiyah Bustanul Atfal IV Kec. Jelutung.

\section{- Teknik dan Alat Pengumpulan Data}

Teknik pengumpulan data dalam penelitian ini adalah wawancara, observasi, dan diskusi.

\section{- Alat Pengumpulan Data}

Alat pengumpulan data dalam PTS ini sebagai berikut. 
a. Wawancara menggunakan panduan wawancara untuk mengetahui kemampuan awal yang dimiliki guru tentang Rencana Pelaksanaan Pembelajaran.

b. Observasi menggunakan lembar observasi untuk mengetahui komponen RPPH yang telah dibuat dan yang belum dibuat oleh guru.

c. Diskusi dilakukan dengan maksud untuk sharing pendapat antara peneliti dengan guru.

\section{- Prosedur Penelitian}

Penelitian Tindakan Sekolah merupakan penelitian yang bersiklus, artinya penelitian dilakukan secara berulang dan berkelanjutan sampai tujuan penelitian dapat tercapai."

\section{- Rencana Pelaksanaan}

Rencana pelaksanaan dilakukan dalam dua siklus yaitu:

1. Siklus Pertama (Siklus I)

2. Siklus Kedua (Siklus II)

\section{- Indikator Pencapaian Hasil}

Peneliti mengharapkan secara rinci indikator pencapaian hasil paling rendah $78 \%$.

\section{HASIL DAN PEMBAHASAN PENELITIAN}

\section{Deskripsi Hasil Penelitian}

Dari hasil wawancara terhadap enam orang guru, peneliti memperoleh informasi bahwa enam dari semua guru (Delapan orang) belum tahu kerangka penyusunan RPPH, hanya sekolah yang memiliki dokumen standar proses (satu buah), hanya dua orang guru yang pernah mengikuti pelatihan pengembangan RPPH, umumnya guru mengadopsi dan mengadaptasi RPPH, kebanyakan guru tidak tahu dan tidak paham menyusun RPPH secara lengkap, mereka setuju bahwa guru harus menggunakan RPPH dalam melaksanakan proses pembelajaran yang dapat dijadikan acuan/pedoman dalam proses pembelajaran. Selain itu, kebanyakan guru belum tahu dengan komponen-komponen RPPH secara lengkap. 
Berdasarkan hasil observasi peneliti terhadap enam RPPH yang dibuat guru (khusus pada siklus I), diperoleh informasi/data bahwa masih ada guru yang tidak melengkapi RPPH-nya dengan komponen dan sub-subkomponen RPPH tertentu, misalnya komponen indikator dan penilaian hasil belajar. Rumusan kegiatan siswa pada komponen langkah-langkah kegiatan pembelajaran masih kurang tajam, interaktif, inspiratif, menantang, dan sistematis.

Dilihat dari segi kompetensi guru, terjadi peningkatan dalam menyusun Rencana Pelaksanaan Pembelajaran dari siklus ke siklus . Hal itu dapat dilihat pada lampiran Rekapitulasi Hasil Penyusunan RPPH dari Siklus ke Siklus (Lampiran 4).

\section{- Siklus I (Pertama)}

Siklus pertama terdiri dari empat tahap yakni: (1) perencanaan, (2) pelaksanaan, (3) observasi, dan (4) refleksi seperti berikut ini.

1. Perencanaan ( Planning)

a. Membuat lembar wawancara

b. Membuat format/instrumen penilaian RPPH

c. Membuat format rekapitulasi hasil penyusunan RPPH siklus I dan II

d. Membuat format rekapitulasi hasil penyusunan RPPH dari siklus ke siklus

2. Pelaksanaan (Acting)

Pada saat awal siklus pertama indikator pencapaian hasil dari setiap komponen RPPH belum sesuai/tercapai seperti rencana/keinginan peneliti. Hal itu dibuktikan dengan masih adanya komponen RPPH yang belum dibuat oleh guru. Sebelas komponen RPPH yakni: (1) Identitas Program, (2) Materi (3) Alat dan Bahan (4) Kegiatan Pembukaan (5) Kegiatan inti (6) Kegiatan Pentup (7) Rencana Penilaian. Hasil observasi pada siklus kesatu dapat dideskripsikan berikut ini:

Observasi dilaksanakan Sabtu, 30 Agustus 2016, terhadap enam orang guru. Semuanya menyusun RPPH, tapi masih ada guru yang belum melengkapi RPPH-nya baik dengan komponen maupun sub-sub komponen RPPH tertentu. Satu orang tidak melengkapi RPPH-nya dengan komponen indikator pencapaian 
kompetensi. Untuk komponen penilaian hasil belajar, dapat dikemukakan sebagai berikut.

- Satu orang tidak melengkapinya dengan teknik, bentuk instrumen.

- Satu orang tidak melengkapinya dengan teknik, bentuk instumen

- Satu orang tidak melengkapinya dengan teknik, bentuk instumen

- Satu orang tidak melengkapinya dengan teknik, bentuk instumen

- Satu orang tidak melengkapinya dengan teknik, bentuk instumen

- Satu orang tidak melengkapinya dengan teknik, bentuk instumen

- Selanjutnya mereka dibimbing dan disarankan untuk melengkapinya.

\section{- Siklus II (Kedua)}

Siklus kedua juga terdiri dari empat tahap yakni: (1) Identitas Program, (2) Materi (3) Alat dan Bahan (4) Kegiatan Pembukaan. Hasil observasi pada siklus kedua dapat dideskripsikan berikut ini:

Observasi dilaksanakan Senin, 22 September 2016, terhadap enam orang guru. Semuanya menyusun RPPH, tapi masih ada guru yang keliru dalam menentukan kegiatan siswa dalam langkah-langkah kegiatan pembelajaran dan metode pembelajaran, serta tidak memilah/ menguraikan materi pembelajaran dalam sub-sub materi. Untuk komponen penilaian hasil belajar, dapat dikemukakan sebagai berikut.

- Satu orang keliru dalam menentukan teknik dan bentuk instrumennya.

- Satu orang keliru dalam menentukan bentuk instrumen berdasarkan teknik penilaian yang dipilih.

- Dua orang kurang jelas dalam memberikan penilaian hasil kerja anak.

- Satu orang tidak menuliskan tingkat pencapaian perkembangan pada buku penialaian anak.

\section{Pembahasan}

Penelitian Tindakan Sekolah dilaksanakan di TK Aisyiyah Bustanul Atfal IV Kec. Jelutung yang merupakan sekolah peneliti berstatus swasta, terdiri atas delapan guru, dan dilaksanakan dalam dua siklus. Kedelapan guru tersebut 
menunjukkan sikap yang baik dan termotivasi dalam menyusun RPPH dengan lengkap. Hal ini peneliti ketahui dari hasil pengamatan pada saat melakukan wawancara dan bimbingan penyusunan RPPH.

Selanjutnya dilihat dari kompetensi guru dalam menyusun RPPH, terjadi peningkatan dari siklus ke siklus.

\section{Komponen Identitas Mata Pelajaran}

Pada siklus pertama semua guru (delapan orang) mencantumkan identitas materi kegiatan dalam RPPH-nya (melengkapi RPPH-nya dengan identitas mata pelajaran). Jika dipersentasekan, 84\%. Tiga orang guru mendapat skor 3 (baik) dan tiga orang mendapat skor 4 (sangat baik). Pada siklus kedua enam guru tersebut mencantumkan identitas Materi dalam RPPH-nya. Semuanya mendapat skor 4 (sangat baik). Jika dipersentasekan, 100\%, terjadi peningkatan 16\% dari siklus I.

\section{Komponen Standar Kompetensi}

Pada siklus pertama semua guru (Enam orang) mencantumkan standar kompetensi dalam RPPH-nya (melengkapi RPPH-nya dengan standar kompetensi). Jika dipersentasekan, 81\%. Masing-masing satu orang guru mendapat skor 1, 2, dan 3 (kurang baik, cukup baik, dan baik). Lima orang guru mendapat skor 4 (sangat baik). Pada siklus kedua enam guru tersebut mencantumkan standar kompetensi dalam RPPH-nya. Tiga orang mendapat skor 3 (baik) dan Tiga orang mendapat skor 4 (sangat baik). Jika dipersentasekan, 94\%, terjadi peningkatan $13 \%$ dari siklus I.

\section{Komponen Kompetensi Dasar}

Pada siklus pertama semua guru (Enam orang) mencantumkan kompetensi dasar dalam RPPH-nya (melengkapi RPPH-nya dengan kompetensi dasar). Jika dipersentasekan, $81 \%$. Satu orang guru masing-masing mendapat skor 1, 2, dan 3 (kurang baik, cukup baik, dan baik). Lima orang guru mendapat skor 4 (sangat baik). Pada siklus kedua enam guru tersebut mencantumkan kompetensi dasar dalam RPPH-nya. Dua orang mendapat skor 3 (baik) dan empat orang mendapat skor 4 (sangat baik). Jika dipersentasekan, 94\%, terjadi peningkatan 13\% dari siklus I.

VOLUME 2, NO. 1 Januari - Juni 2019 


\section{Komponen Indikator Pencapaian Kompetensi}

Pada siklus pertama enam orang guru mencantumkan indikator pencapaian kompetensi dalam RPPH-nya (melengkapi RPPH-nya dengan indikator pencapaian kompetensi). Sedangkan enam orang tidak mencantumkan/melengkapinya. Jika dipersentasekan, 56\%. Enam orang guru masing-masing mendapat skor 1 dan 2 (kurang baik dan cukup baik). Dua orang guru mendapat skor 3 (baik). Pada siklus kedua enam guru tersebut mencantumkan indikator pencapaian kompetensi dalam RPPH-nya. Lima orang mendapat skor 3 (baik) dan satu orang mendapat skor 4 (sangat baik). Jika dipersentasekan, $78 \%$, terjadi peningkatan $22 \%$ dari siklus I.

\section{Komponen Tujuan Pembelajaran}

Pada siklus pertama semua guru (delapan orang) mencantumkan tujuan pembelajaran dalam RPPH-nya (melengkapi RPPH-nya dengan tujuan pembelajaran). Jika dipersentasekan, 63\%. Satu orang guru mendapat skor 1 (kurang baik), dua orang mendapat skor 2 (cukup baik), dan Tiga orang mendapat skor 3 (baik). Pada siklus kedua enam guru tersebut mencantumkan tujuan pembelajaran dalam RPPH-nya. Tiga orang mendapat skor 3 (baik) dan tiga orang mendapat skor 4 (sangat baik). Jika dipersentasekan, 84\%, terjadi peningkatan $21 \%$ dari siklus I.

\section{Komponen Materi Ajar}

Pada siklus pertama semua guru (delapan orang) mencantumkan materi ajar dalam RPPH-nya (melengkapi RPPH-nya dengan materi ajar). Jika dipersentasekan, 66\%. Satu orang guru masing-masing mendapat skor 1 dan 4 (kurang baik dan sangat baik), dua orang mendapat skor 2 (cukup baik), dan empat orang mendapat skor 3 (baik). Pada siklus kedua kedelapan guru tersebut mencantumkan materi ajar dalam RPPH-nya. Enam orang mendapat skor 3 (baik) dan dua orang mendapat skor 4 (sangat baik). Jika dipersentasekan, 81\%, terjadi peningkatan $15 \%$ dari siklus I.

\section{Komponen Alokasi Waktu}

Pada siklus pertama semua guru (delapan orang) mencantumkan alokasi waktu dalam RPPH-nya (melengkapi RPPH-nya dengan alokasi waktu). 
Semuanya mendapat skor 3 (baik). Jika dipersentasekan, 75\%. Pada siklus kedua kedelapan guru tersebut mencantumkan alokasi waktu dalam RPPH-nya. Tiga orang mendapat skor 3 (baik) dan lima orang mendapat skor 4 (sangat baik). Jika dipersentasekan, $91 \%$, terjadi peningkatan $16 \%$ dari siklus I.

\section{Komponen Metode Pembelajaran}

Pada siklus pertama semua guru (delapan orang) mencantumkan metode pembelajaran dalam RPPH-nya (melengkapi RPPH-nya dengan metode pembelajaran). Jika dipersentasekan, 72\%. Dua orang guru mendapat skor 2 (cukup baik), lima orang mendapat skor 3 (baik), dan satu orang mendapat skor 4 (sangat baik). Pada siklus kedua kedelapan guru tersebut mencantumkan metode pembelajaran dalam RPPH-nya. Satu orang mendapat skor 2 (cukup baik), enam orang mendapat skor 3 (baik), dan satu orang mendapat skor 4 (sangat baik). Jika dipersentasekan, 75\%, terjadi peningkatan 3\% dari siklus I.

\section{Komponen Langkah-Langkah Kegiatan Pembelajaran}

Pada siklus pertama semua guru (delapan orang) mencantumkan langkahlangkah kegiatan pembelajaran dalam RPPH-nya (melengkapi RPPH-nya dengan langkah-langkah kegiatan pembelajaran). Jika dipersentasekan, 53\%. Tujuh orang guru mendapat skor 2 (cukup baik), sedangkan satu orang mendapat skor 3 (baik). Pada siklus kedua kedelapan guru tersebut mencantumkan langkahlangkah kegiatan pembelajaran dalam RPPH-nya. Satu orang mendapat skor 2 (cukup baik) dan tujuh orang mendapat skor 3 (baik). Jika dipersentasekan, 72\%, terjadi peningkatan $19 \%$ dari siklus I.

\section{Komponen Sumber Belajar}

Pada siklus pertama semua guru (delapan orang) mencantumkan sumber belajar dalam RPPH-nya (melengkapi RPPH-nya dengan sumber belajar). Jika dipersentasekan, 66\%. Tiga orang guru mendapat skor 2 (cukup baik), sedangkan lima orang mendapat skor 3 (baik). Pada siklus kedua kedelapan guru tersebut mencantumkan sumber belajar dalam RPPH-nya. Dua orang mendapat skor 2 (cukup baik) dan enam orang mendapat skor 3 (baik). Jika dipersentasekan, 69\%, terjadi peningkatan $3 \%$ dari siklus I. 


\section{Komponen Penilaian Hasil Belajar}

Pada siklus pertama semua guru (delapan orang) mencantumkan penilaian hasil belajar dalam RPPH-nya meskipun sub-sub komponennya teknik penilaian kurang lengkap. Jika dipersentasekan, 56\%. Dua orang guru masing-masing mendapat skor 1 dan 3 (kurang baik dan baik), tiga orang mendapat skor 2 (cukup baik), dan satu orang mendapat skor 4 (sangat baik). Pada siklus kedua kedelapan guru tersebut mencantumkan penilaian hasil belajar dalam RPPH-nya meskipun ada guru yang masih keliru dalam menentukan teknik dan bentuk penilaiannya. Tujuh orang mendapat skor 3 (baik) dan satu orang mendapat skor 4 (sangat baik). Jika dipersentasekan, 78\%, terjadi peningkatan $22 \%$ dari siklus I.

Berdasarkan pembahasan di atas terjadi peningkatan kompetensi guru dalam menyusun RPPH. Pada siklus I nilai rata-rata komponen RPPH 69\%, pada siklus II nilai rata-rata komponen RPPH 83\%, terjadi peningkatan 14\%. Untuk mengetahui lebih jelas peningkatan setiap komponen RPPH, dapat dilihat pada lampiran Rekapitulasi Hasil Penyusunan RPPH dari Siklus ke Siklus TK Aisyiyah Bustanul Atfal IV Kec. Jelutung (Lampiran 4).

\section{E. KESIMPULAN DAN SARAN}

\section{- Kesimpulan}

Berdasarkan hasil Penelitian Tindakan Sekolah (PTS) dapat disimpulkan sebagai berikut.

1. Bimbingan berkelanjutan dapat meningkatkan motivasi guru dalam menyusun RPPH dengan lengkap. Guru menunjukkan keseriusan dalam memahami dan menyusun RPPH apalagi setelah mendapatkan bimbingan pengembangan/penyusunan RPPH dari peneliti. Informasi ini peneliti peroleh dari hasil pengamatan pada saat mengadakan wawancara dan bimbingan pengembangan/penyusunan RPPH kepada para guru.

2. Bimbingan berkelanjutan dapat meningkatkan kompetensi guru dalam menyusun RPPH. Hal itu dapat dibuktikan dari hasil observasi/pengamatan yang memperlihatkan bahwa terjadi peningkatan kompetensi guru dalam 
menyusun RPPH dari siklus ke siklus. Pada siklus I nilai rata-rata komponen RPPH 69\% dan pada siklus II 83\%. Jadi, terjadi peningkatan 14\% dari siklus I.

- Saran

Telah terbukti bahwa dengan bimbingan berkelanjutan dapat meningkatkan motivasi dan kompetensi guru dalam menyusun RPP. Oleh karena itu, peneliti menyampaikan beberapa saran sebagai berikut.

1. Motivasi yang sudah tertanam khususnya dalam penyusunan RPP hendaknya terus dipertahankan dan ditingkatkan/ dikembangkan .

2. RPP yang disusun/dibuat hendaknya mengandung komponen-komponen RPP secara lengkap dan baik karena RPP merupakan acuan/pedoman dalam melaksanakan pembelajaran.

\section{DAFTAR PUSTAKA}

Daradjat, Zakiyah. 1980. Kepribadian Guru. Jakarta: Bulan Bintang.

Dewi, Kurniawati Eni. 2009. Pengembangan Bahan Ajar Bahasa Dan Sastra Indonesia Dengan Pendekatan Tematis. Tesis. Surakarta: Program Pascasarjana Universitas Sebelas Maret.

Depdiknas. 2003. UU RI No. 20 Tahun 2003 tentang Sistem Pendidikan Nasional. Jakarta: Depdiknas.

2004. Standar Kompetensi Guru Sekolah Dasar. Jakarta: Depdiknas.

2005. UU RI No. 14 Tahun 2005 tentang Guru dan Dosen. Jakarta: Depdiknas.

2005. Standar Nasional Pendidikan. Jakarta: Depdiknas.

2007. Permendiknas RI No. 41 Tahun 2007a tentang Standar Proses. Jakarta: Depdiknas.

2007. Permendiknas RI No. 12 Tahun 2007b tentang Standar Pengawas Sekolah/Madrasah. Jakarata: Depdiknas.

2008. Perangkat Pembelajaran Kurikulum Tingkat Satuan Pembelajaran SMA. Jakarta.

2008. Alat Penilaian Kemampuan Guru. Jakarta: Depdiknas.

2009. Petunjuk Teknis Pembuatan Laporan Penelitian Tindakan Sekolah Sebagai Karya Tulis Ilmiah Dalam Kegiatan Pengembangan Profesi Pengawas Sekolah. Jakarta. 
Fatihah, RM . 2008. Pengertian konseling (Http://eko13.wordpress.com, diakses 19 Maret 2009).

Imron, Ali. 2000. Pembinaan Guru Di Indonesia. Malang: Pustaka Jaya.

Kemendiknas. 2010. Penelitian Tindakan Sekolah. Jakarta. 2010. Supervisi Akademik. Jakarta.

Kumaidi. 2008. Sistem Sertifikasi (http://massofa.wordpress.com diakses 10 Agustus 2009).

Nawawi, Hadari. 1985. Metode Penelitian Bidang Sosial. Yogyakarta: Gadjah Mada University Press.

Nurhadi. 2004. Kurikulum 2004. Jakarta: PT Gramedia Widiasarana Indonesia.

Pidarta, Made. 1992. Pemikiran Tentang Supervisi Pendidikan. Jakarta: Bumi Aksara.

Sudjana, Nana. 2009. Standar Kompetensi Pengawas Dimensi dan Indikator. Jakarta : Binamitra Publishing.

Suharjono. 2003. Menyusun Usulan Penelitian. Jakarta: Makalah Disajikan pada Kegiatan Pelatihan Tehnis Tenaga Fungsional Pengawas.

Suparlan. 2005. Menjadi Guru Efektif. Yogyakarta: Hikayat Publishing. 2006. Guru Sebagai Profesi. Yogyakarta: Hikayat Publishing.

Tim Redaksi. Kamus Besar Bahasa Indonesia. Edisi kedua.

Rika Ariyani, Editor Jurnal Literasiologi. Literasi Kita Indonesia. STAI Syekh Maulana Qori. Merangin Bangko.

Pohan, S. (2018). Manajemen sekolah: wujudkan guru profesional. Tarbawi : Jurnal Ilmu Pendidikan, 14(2), 51-62. https://doi.org/10.32939/tarbawi.v14i2.265

Sumarto, S. (2016). Tugas Profesional Kepala Madrasah Sebagai Supervisor Dalam Meningkatkan Mutu Pendidikan. Ri'ayah: Journal of Social and Religious, 1(02), 168-187. 